\section{Abderhalden's fraud still wins him some supporters}

\section{SIR - Your Misconduct Special (Nature} 445, 240-245; 2007) calls South Korean stem-cell biologist Woo Suk Hwang "arguably the highest-profile fraudster ever”. A look into the history of fraud in the biomedical sciences reveals at least one other strong candidate for this title.

In the area of human reproductive biology, the Korean scandal is overshadowed by the case of the influential German physiologist Emil Abderhalden (1877-1950) and the non-existent Abwehrfermente or 'defence enzymes' he claimed to have discovered. The shocking story of his fraudulent work, over a long period, has been told by Ute Deichmann and Benno Müller-Hill (Nature 393, 109-111; 1998).

Briefly, Abderhalden - a powerful and influential scientist - published a first paper on his "most important discovery" in 1909, and a widely read and translated book on the subject followed in 1912 (E. Abderhalden Abwehrfermente: Die Abderhaldensche Reaktion Theodor Steinkopff, 7th edn, 1944). The 'Abderhalden reaction' was used as a pregnancy test, and to treat various diseases. From 1914 on, biochemists tried to repeat Abderhalden's experiments, but failed to achieve this. A number of experts published their negative findings, but Abderhalden continued to publish fabricated data until his death.

In 1998, Deichmann and Müller-Hill asked whether such a fraud could happen again. Hwang's case showed that it could - but that was, at least, quickly exposed and denounced.

Yet Abderhalden is still regarded by some as one of the founding fathers of modern biochemistry (see M. Kaasch Acta Hist. Leopold. 36, 145-210; 2000). The nomination database for the Nobel Prize in Physiology or Medicine reveals that, between 1913 and 1936, he was listed 49 times as a nominee for this most prestigious prize. Sixteen times, the motivation was Abderhalden's "work on defence enzymes". Twice, his pregnancy test is highlighted, and in one case "all the work Abderhalden has done" is listed in this database (see http://nobelprize.org/ nomination/medicine/database.html). There is no mention of his fraud on the Nobel site. These numerous nominations, combined with Abderhalden's despotism, narcissism and influence as a science manager, prevented his work from being rejected as an outright scientific fraud.

Worst of all, Abderhalden's myth is still alive. For instance, on the German site of the Internet encyclopaedia Wikipedia, Emil Abderhalden was until this year listed as an "important physiologist and discoverer of the specific Abderhaldensche Abwehrfermente
- he developed the first pregnancy test". Similar admiring descriptions can still be found in the latest editions of German lexica such as Die Zeit: Das Lexikon 2005 (www. zeit-lexikon.de/index.php). The authors refer to Abderhalden's book, which remains available in libraries and second-hand, and is still taken seriously in the popular literature on biomedicine.

\section{U. Kutschera}

Institute of Biology, University of Kassel,

Heinrich-Plett-Strasse 40,

D-34109 Kassel, Germany

\section{A Moon base offers more than just a good view}

SIR - Your Editorial "Brave blue world" (Nature 445, 459; 2007) correctly points out that Antarctic science "has been central to the great project of understanding the changes that humans are inflicting upon the Earth". You go on to say that "the only input that lunar activity will provide for the study of Earth is the iconic and inspiring sight of a blue planet in a black sky over a grey desert".

But when Antarctic exploration began, the concept of global warming that had been introduced by G. S. Callendar ${ }^{1}$ in 1938 was only beginning to be taken seriously ${ }^{2}$. Studies in the 1950s focused mainly on ocean turnover of carbon dioxide. That an Antarctic base would reveal humanity's contribution to climate change with such clarity was not a driver for building a base, and ultimately many findings were serendipitous - we certainly were not looking for an ozone hole, for example.

If the only goal of an Antarctic base was to gather atmospheric data, it would have been easier and much cheaper to use aircraft rather than build a base. Similarly, if the only goal of a Moon base is to observe Earth, it is cheaper and easier to use satellites. This misses the main point of establishing a distant outpost. In general, if one picks a single function of the outpost, it is possible to find a cheaper and easier way to perform that particular function. But the multiple goals of a broad scientific expedition help each other succeed in many ways. Antarctic discoveries were made because we established long-term monitoring in a scientifically interesting place with no guarantees of the ultimate importance of the science.

Similarly, the Moon is a scientifically interesting place to explore and, although there are no guarantees, long-term monitoring of the entire Earth, as visible from the Moon, is a pretty good bet to provide important discoveries that we are unable to anticipate at present. Just as the synergies of exploration, oceanic, atmospheric, geological, biological and meteoritic investigations combined to yield rich results from
Antarctica, we will one day be amazed by the wealth of knowledge gained from the Moon. Dan Barry

NASA astronaut (retired), Denbar Robotics, South Hadley, Massachusetts 01075, USA.

1. Callendar, G. S. Q. J. R. Meteorol. Soc. 64, 223-240 (1938)

2. Revelle, R. \& Seuss, H. E. Tellus 9, 18-27 (1957).

\section{Fossils: new journal will oppose illegal trade}

SIR - The Association of Applied

Paleontological Sciences (AAPS), of which I am president, changed its name in 2002 from the American Association of Paleontological Suppliers, to reflect our international and broad-based membership. It had nothing to do with the impending launch of the Journal of Paleontological Sciences (JPS), as claimed in your News story "Palaeontology journal will 'fuel black market"' (Nature 445, 234-235; 2007, and Correspondence Nature 445, 709; 2007).

The AAPS actively supports efforts to locate and retrieve stolen specimens. The journal's submission guidelines state that the JPS will not publish fossils that cannot be legally exported from their home country, or where ownership cannot be verified. The view attributed to Mark Goodwin of the University of California Museum of Paleontology in Berkeley — that the new journal will encourage commercial fossil collection and hence increased illegal collecting activity and trade on public lands - is incorrect. Authors who publish in the JPS must abide by the AAPS code of ethics, and must agree to make their published specimen(s) available for study, as do many other scientific publications (see www.aaps-journal.org).

Commercial fossil trading in the United States started with quarrymen in New Jersey selling fossils to Joseph Leidy during the mid1800 s. By the 1870 s, professional collectors were busy filling museums with dinosaurs and other fossils, by accepting the risks of exploration, discovery and excavation, then selling their discoveries, and in some cases collecting fossils on a contract basis. Visit any number of prestigious institutions and you will see magnificent displays whose very existence is owed to professional collectors.

The tax deduction allowed for fossil donations under US tax law (which is not a government policy) is not "a bid to confront these activities", but is a long-standing policy having nothing to do with fossils per se. You can donate your Grandpa's spittoon to a museum and get the same write-off. The donation doesn't have to be to a museum: any 501(C-3) non-profit corporation can accept tax-deductible donations.

Michael Triebold

Triebold Paleontology and Rocky Mountain Dinosaur Resource Center, 201 South Fairview Street, Woodland Park, Colorado 80863, USA 